\title{
Oral Transforming Growth Factor- $\alpha$ Enhances Jejunal Mucosal Recovery and Electrical Resistance in Piglet Rotavirus Enteritis
}

\author{
J. MARC RHOADS, MARTIN H. ULSHEN, EMMANUEL O. KEKU, WUNIAN CHEN, \\ HOSAM M. KANDIL, J. PAUL WOODARD, SHIH-CHIA C. LIU, C. RANDALL FULLER, \\ H. LEE LEARY, JR., AND JAMES G. LECCE
}

\begin{abstract}
Departments of Pediatrics [J.M.R., M.H.U., E.O.K., W.C., H.M.K., J.P.W., C.R.F.] and School of Public Health [S.-C.C.L.], University of North Carolina, Chapel Hill, North Carolina 27599; North Carolina State University, Department of Animal Sciences, Raleigh, North Carolina 27607 [J.G.L.]; and Mead Johnson Nutritional Group, Evansville, Indiana [H.L.L.] and the Center for Gastrointestinal Biology and Disease, Chapel Hill and Raleigh, North Carolina
\end{abstract}

\begin{abstract}
WHADATHABSTRACT
A randomized, investigator-masked trial determined the effects of oral recombinant human transforming growth factor- $\alpha$ (TGF $\alpha$ ) on jejunal mucosal recovery in 75 piglets with rotavirus diarrhea. Rotavirus inoculation of artificially reared piglets induced subtotal $(\sim 50 \%)$ villus atrophy and watery diarrhea. Dietary $\mathrm{TGF} \alpha$ was associated with significant restoration of villus surface area by $4 \mathrm{~d}$ postinoculation (p.i.) and complete restoration by $8 \mathrm{~d}$ p.i., whereas saline-treated animals required $12 \mathrm{~d}$ for recovery. Jejunal segments from clinically recovered $\mathrm{TGF} \alpha$ treated piglets showed an increase in electrical resistance across the epithelial barrier in vitro which was proportional to villus height. TGF $\alpha$ treatment for $12 \mathrm{~d}$ also produced a $30-50 \%$ increase in jejunal mucosal mass (protein content and wet weight), compared with the corresponding values in salinetreated piglets and in uninfected controls. However, oral TGF $\alpha$ did not hasten the resolution of diarrhea, enhance the specific
\end{abstract}

For treatment of infants with severe acute diarrhea, only fiber-containing formulas, smectite (a mineral clay), and bismuth subsalicylate have been shown to improve stool consistency and reduce the duration of diarrhea (1-4). However, no treatment has been demonstrated to facilitate mucosal recovery in infants with acute intestinal damage. Breast-fed infants in developing countries have less severe diarrhea and decreased diarrheal mortality compared with formula-fed infants (5). EGF, a well characterized peptide, is abundant in human milk, duodenal secretions, and saliva and is known to stimulate proliferation of gastrointestinal epithelial cells $(6,7)$. TGF $\alpha$ is

Received August 2, 1994, accepted March 9, 1995

Correspondence and reprint requests: J. Marc Rhoads, Department of Pediatrics, CB 7220, Division of Gastroenterology, University of North Carolina, Chapel Hill, Chapel Hill, NC 27599 .

Supported by the Mead Johnson Nutritional Group, Evansville, IN and National Institutes of Health KO8 00945 . activities of jejunal mucosal digestive enzymes, or increase jejunal glucose-stimulated $\mathrm{Na}^{+}$absorption in vitro. We conclude that dietary TGF $\alpha$ stimulates jejunal mucosal hypertrophy, improves barrier function, and enhances regrowth of villi in rotavirus enteritis; however, it does not facilitate the restoration of functional activity or mucosal digestive enzymes. Oral TGF $\alpha$ can facilitate intestinal epithelial recovery in diseases associated with mucosal damage. (Pediatr Res 38: 173-181, 1995)

EGF, epidermal growth factor

TGF $\alpha$, transforming growth factor- $\alpha$

$\mathbf{I}_{\mathrm{sc}}$, short-circuit current

p.i., postinoculation

PD, potential difference also found in high concentration in human milk (8). TGF $\alpha$ is a 50 -amino acid polypeptide which has $35 \%$ sequence homology with EGF and which binds to and activates the EGF receptor (8). TGF $\alpha$ is remarkably homologous among mammalian species (94-100\% homology). In a variety of systems, TGF $\alpha$ is more potent and less likely to cause down-regulation of EGF receptors in comparison to EGF (9).

Rotavirus is the most commonly recognized enteric pathogen in infants (10), causing a well described injury to the villous epithelium. We have previously characterized a reproducible porcine model that closely resembles the clinical and histologic features of human rotavirus enteritis (11). Using this model, we determined the effects of exogenous administration of TGF $\alpha$ on the clinical course and intestinal mucosal structure, enzyme activities, and electrical characteristics in newborn piglets with watery diarrhea. 


\section{METHODS}

Animals. Piglets were obtained from a herd of cross-bred swine maintained by the North Carolina School of Agricultural and Life Sciences. Before farrowing, sows were brought to an intensive care facility and scrubbed daily with povidoneiodine. The piglets were caught on towels, taken to an isolated facility, placed in individual cages, and fed hourly $(300 \mathrm{~mL} /$ $\mathrm{kg} /$ day) with an automatic feeding machine (12) an artificial formula based on cow's nonfat milk solids. This formula has been shown to have no growth stimulatory effect in vitro (13). Only healthy animals of normal birth weight were enrolled.

Colostrum-deprived piglets are agammaglobulinemic and are ideal for studies of enteritis because they are uniformly susceptible to infection and are not at risk for acquiring enteric infections from the sow. On d 4-5 of life, which is the optimal time for inducing infection (14), 75 animals were given in 10 $\mathrm{mL}$ of diet approximately $10^{6}$ group A porcine rotavirus particles (derived from a frozen stock of fecal supernatant of rotavirus-infected piglets). Previous studies showed that animals inoculated in the first week of life uniformly develop viral enteritis, with some variability in the severity of the mucosal (villous) lesion (12). Body weight was checked every other day; and stool consistency was graded as follows: 1, solid feces; 2, soft, looser than normal stools; 3, liquid diarrheal feces. Stool was assayed for rotavirus antigen by Virogen Rotatest (Wampole Laboratories, Cranbury, NJ).

On the day of inoculation, littermates were randomized to one of four groups receiving human recombinant $\mathrm{TGF} \alpha$ at concentrations of $0,15,60$, or $240 \mu \mathrm{g} / \mathrm{L}$ of formula. Vials of $\mathrm{TGF} \alpha$ at different concentration were letter coded by the Mead-Johnson Nutritional Group so that investigators were unaware of treatment group. The code was not broken until all enzyme assays and transport studies were completed. Additionally, studies of intestinal morphology were performed by two examiners who were masked with respect to treatment group. Because artificially fed piglets consumed all of their diet except for a brief period $(6-12 \mathrm{~h})$ after rotavirus inoculation, we assumed the TGF $\alpha$ administered was consumed fully. TGF $\alpha$ was kept frozen in aliquots at $-20^{\circ} \mathrm{C}$, thawed, and added to diet daily at a dilution of $1: 10^{4}$. The lowest concentration of TGF $\alpha(15 \mu \mathrm{g} / \mathrm{L})$ was similar to that of TGF $\alpha$ in human colostrum $(2-7 \mu \mathrm{g} / \mathrm{L})(8)$. For comparison, porcine and human milk contain EGF at about $150 \mu \mathrm{g} / \mathrm{L}(6)$.

Animals were fasted for $4-8 \mathrm{~h}$ before study, anesthetized with 50-70 mg ketamine i.m., and killed with an injection of 2-3 g of sodium pentobarbital. The entire small bowel beginning $10 \mathrm{~cm}$ distal to the suspensory ligament was removed. The mid-jejunum was studied because previous experiments have shown that this is the most severely affected region in porcine rotavirus enteritis (12). A $20-\mathrm{cm}$ segment obtained at the mid-point of the small intestine was removed and placed in oxygenated Ringer buffer. A $10-\mathrm{cm}$ portion, measured under uniform tension of a 10 -g weight, was scraped and homogenized for enzyme, protein, and DNA assays, as described below. The remaining $10 \mathrm{~cm}$ were placed in oxygenated transport buffer for studies of tissue bioelectric properties. Two $0.5-1-\mathrm{cm}$ segments were placed in $10 \%$ formalin for light microscopic evaluation and in Carnoy's fixative for subsequent crypt cell dissection.

All measurements and assays were made by observers unaware of the coding system. Comparison data were obtained from 82 identically reared, uninfected animals. Infected piglets at 8,12 , and $16 \mathrm{~d}$ of age were compared with control animals aged $8-10,10-13$, and $14-19 \mathrm{~d}$. We did not study uninfected and rotavirus-exposed piglets concurrently because rotavirus outbreaks occur despite assiduous disinfection of the facility. Some of the enzyme and morphologic data for uninfected animals were reported in previous studies $(12,15)$.

Assays of mucosal enzymes and mass. Mucosa was scraped from the jejunal segments on an iced glass plate, divided in half, and homogenized in two iced buffers. The first sample was homogenized $(0.1 \mathrm{~g}$ of mucosa $/ \mathrm{mL}$ of buffer $)$ in $0.2 \mathrm{M}$

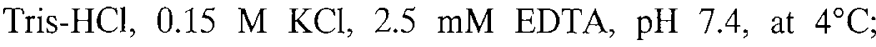
immediately frozen in aliquots at $-70^{\circ} \mathrm{C}$; and assayed within 2-3 wk for lactase, sucrase, alkaline phosphatase, and total and ouabain-inhibitable ATPase $\left(\mathrm{Na}^{+}, \mathrm{K}^{+}\right.$-ATPase) activities, as previously described $(12,16)$. The second scraping was homogenized in 20 volumes of iced $10 \mathrm{mM}$ Tris- $\mathrm{HCl}, \mathrm{pH} 7.2$, for ornithine decarboxylase determination. Measurement of DNA content was performed using a modified fluorescent dye microassay technique (16). Protein was measured by the method of Lowry et al. (17).

Ornithine decarboxylase activity was measured in duplicate by a modification of a standard method (7). The 1:20 (wt/vol) homogenate was sonicated and spun at $15,000 \times g$ for $30 \mathrm{~min}$ at $4^{\circ} \mathrm{C}$. A $90-\mu \mathrm{L}$ aliquot of the supernatant was placed in an iced $16 \times 100-\mathrm{mm}$ glass tube containing $0.5 \mu \mathrm{Ci}$ of DL$\left[{ }^{14} \mathrm{C}\right.$ ]ornithine in $50 \mu \mathrm{L}$ of a solution of $12 \mathrm{mM}$ dithiothreitol and $1.72 \mathrm{mM}$ DL-ornithine. A $7.5-\mu \mathrm{L}$ volume of $1 \mathrm{mM}$ pyridoxal phosphate was then added to this mixture. The tube was sealed immediately with a rubber stopper from which was suspended a plastic center well containing a $13 \times 20$-mm strip of Whatman No. 1 filter paper soaked in $200 \mu \mathrm{L}$ of methylbenzethonium hydroxide. Tubes were incubated in a $37^{\circ} \mathrm{C}$ shaking water bath, and the liberated $\mathrm{CO}_{2}$ was trapped on the filter paper. At 60 min of incubation, the reaction was stopped by injecting $30 \%$ trichloroacetic acid to a final concentration of $10 \%$. After an additional $60 \mathrm{~min}$, the center well was placed in a scintillation vial with $10 \mathrm{~mL}$ of Safety-Solve (Research Products International, Mount Prospect, IL) scintillation cocktail and counted. Nonspecific decarboxylation was evaluated by a simultaneous assay in the presence of $25 \mathrm{mM}$ difluoromethylornithine, a specific inhibitor of ornithine decarboxylase, and subtracted from the total $\mathrm{CO}_{2}$ released.

Electrical measurements. Jejunum was drawn over a plastic rod, incised longitudinally, and stripped of muscularis propria. Tissues mounted between lucite half-chambers exposing an area of $1.13 \mathrm{~cm}^{2}$ were bathed at $37^{\circ} \mathrm{C}$ in $10 \mathrm{~mL}$ of oxygenated buffer containing (in $\mathrm{mM}$ ): $\mathrm{Na} 140, \mathrm{~K} 5.2, \mathrm{Ca} 1.2, \mathrm{Mg} 1.2, \mathrm{Cl}$ $119.8, \mathrm{HCO}_{3} 25, \mathrm{H}_{2} \mathrm{PO}_{4} 0.4$, and $\mathrm{HPO}_{4}$ 2.4, pH 7.4. Indomethacin $(1 \mathrm{mM})$ was present in the Ringer solution during tissue stripping and during the flux experiments to minimize prostaglandin-associated $\mathrm{Cl}^{-}$secretion. To sustain tissue metabolism, $10 \mathrm{mM}$ glucose was added to the serosal buffer, with equimolar mannitol added on the mucosal side. The PD across 
the tissue was measured by calomel electrodes in saturated $\mathrm{KCl}$, attached to agar bridges $(4 \mathrm{~g} / 100 \mathrm{~mL}$, made up in Ringer buffer) positioned near the surface of the tissue. Epithelia were continuously short-circuited with automatic voltage clamps (World Precision Instruments, New Haven, CT), which compensated for the fluid resistance. Tissues were continuously short-circuited, except for 5-s intervals, when the open circuit PD was measured. Conductance was calculated from the open circuit $\mathrm{PD}$ and $\mathrm{I}_{\mathrm{sc}}$ using Ohm's law. After a 90-min equilibration period, $30 \mathrm{mM}$ D-glucose was added to the mucosal side, balanced by serosal mannitol, and $\mathrm{I}_{\mathrm{sc}}$ was measured for a subsequent 20-30 min, until stable. The increment in $\mathrm{I}_{\mathrm{sc}}\left(\Delta \mathrm{I}_{\mathrm{sc}}\right)$ was defined as the difference between the peak $\mathrm{I}_{\mathrm{sc}}$ and basal $\mathrm{I}_{\mathrm{sc}}$.

Intestinal morphology. From each animal, three to eight properly oriented villi and adjacent crypts were identified by an observer masked to treatment group. Images were captured from a Nikon Microphot-FXA with a television camera, and measurements were made by computer-assisted morphometry (Image-Pro II, Media Cybernetics, Silver Spring, MD). Villous surface area was calculated from villus length and width, using geometric principles which assume the villus to be a prefect cylinder, as previously described in detail (18).

Epithelial cell proliferation. Segments of small intestine were fixed in Carnoy's reagent and stored in 70\% ethanol. At the time of analysis, the tissue was rehydrated, stained with Schiff reagent, placed in $45 \%$ acetic acid under a dissecting microscope, and gently teased apart. A coverslip was placed over the tissue, and individual crypts were separated. The number of mitotic figures per crypt was counted with light microscopy. For each segment analyzed, the mean number of mitoses in 10-13 crypts was determined.

Chemicals. Reagents were purchased from Sigma Chemical Co., St. Louis, MO. Rubber stoppers and plastic center wells were purchased from Kontes (Vineland, NJ). Human recombinant TGF $\alpha$ was purchased form Triton Biosciences (Alameda, CA). -DL- $\left[{ }^{14} \mathrm{C}\right]$ Ornithine was purchased from DuPont NEN (Boston, MA). Difluormethylornithine was a gift from Marion Merrell Dow Research Institute (Cincinnati, OH).

Statistics. With the hypothesis that TGF $\alpha$ treatment would stimulate recovery, the Kruskal-Wallis (multiple comparison) test was used to compare data from uninfected and infected pigs. When a significant difference among the five groups was noted, each infected group was compared with the agematched uninfected group with the Mann Whitney $U$ test. To compare daily fecal scores, rotavirus scores, and number of deaths, $\chi^{2}$ statistic was used if frequency in each cell was $\geq 5$; Fisher's exact test was used if $n<5$. For comparison of piglet weights, normal distribution was assumed (because the sample size was large), and a two-sided unpaired $t$ test was used. Data are mean \pm SEM.

These studies were approved by the University of North Carolina and North Carolina State University Animal Care Committees.

\section{RESULTS}

\section{Clinical Course}

Fecal scores (Table 1). Eighty percent of the infected piglets $(60 / 75)$ developed severe watery diarrhea, with onset $1.6 \pm 0.2$ d p.i.. In most cases, explosive diarrhea lasted 1--2 d, followed by loose stools for several more days. One of the infected piglets died with severe diarrhea. By 9 d p.i. only $3 / 32$ piglets had loose stools. There were no significant differences between the four groups of infected piglets (saline or 15,60 , or 240 $\mu \mathrm{g} / \mathrm{L} \mathrm{TGF} \alpha$ ), comparing fecal scores at $\mathrm{d} 4,8$, or 12 .

Weight gain (Table 1). Infected piglets generally grew at a slower rate than uninfected animals. By d 12 p.i., three of the four groups of rotavirus-inoculated animals had failed to reach a mean weight of $3 \mathrm{~kg}$, the weight of normal uninfected piglets at this age $(p<0.05)$. The one exception was the group treated with TGF $\alpha$ at $60 \mu \mathrm{g} / \mathrm{L}$. These piglets had weights similar to those of the uninfected animals.

Rotavirus excretion. Of the 75 inoculated piglets, 61 excreted rotavirus antigen in the stool. Viral excretion began as early as $1 \mathrm{~d}$ p.i. and as late as $7 \mathrm{~d}$ p.i. Twelve of the 14 piglets with stools which were repeatedly negative for rotavirus antigen were ill, with watery diarrhea. Additionally, two piglets had neither diarrhea nor detectable fecal rotavirus antigen, but both were killed at the earliest time point ( $4 \mathrm{~d}$ p.i., saline group). In both of these piglets mucosal enzyme activities

Table 1. Clinical observations of rotavirus-infected pigs: effect of enteral $T G F \alpha$

\begin{tabular}{|c|c|c|c|c|c|}
\hline \multirow[b]{3}{*}{ Day post-inoculation } & \multirow[b]{3}{*}{ Uninfected } & \multicolumn{4}{|c|}{ Rotavirus-infected } \\
\hline & & \multirow[b]{2}{*}{ Saline } & \multicolumn{3}{|c|}{ TGF- $\alpha$-treated } \\
\hline & & & $15 \mu \mathrm{g} / \mathrm{L}$ & $60 \mu \mathrm{g} / \mathrm{L}$ & $240 \mu \mathrm{g} / \mathrm{L}$ \\
\hline \multicolumn{6}{|c|}{ I. Fecal scores (mean \pm SEM) $(1=$ solid stool, $2=$ loose stool, $3=$ watery diarrhea). Percent with watery diarrhea is in italics } \\
\hline 4 & $\begin{array}{c}1.1 \pm 0.1(28) \\
0\end{array}$ & $\begin{array}{c}2.2 \pm 0.2(19) \\
47\end{array}$ & $\begin{array}{c}1.9 \pm 0.2(18) \\
39\end{array}$ & $\begin{array}{c}2.1 \pm 0.2(16) \\
31\end{array}$ & $\begin{array}{c}2.0 \pm 0.2(17) \\
35\end{array}$ \\
\hline \multirow[t]{2}{*}{8} & $1.2 \pm 0.1(25)$ & $1.4 \pm 0.2(14)$ & $1.2 \pm 0.2(13)$ & $1.2 \pm 0.2(13)$ & $1.7 \pm 0.3(12)$ \\
\hline & 0 & 7 & 15 & 8 & 25 \\
\hline \multirow[t]{2}{*}{12} & $1.2 \pm 0.1(10)$ & $1.0 \pm 0(8)$ & $1.0 \pm 0(9)$ & $1.0 \pm 0(7)$ & $1.0 \pm 0(5)$ \\
\hline & 0 & 0 & 0 & 0 & 0 \\
\hline \multicolumn{6}{|l|}{ II. Weight (kg) } \\
\hline 4 & $1.83 \pm 0.50$ & $1.67 \pm 0.12$ & $1.65 \pm 0.12$ & $1.75 \pm 0.06$ & $1.80 \pm 0.06$ \\
\hline 8 & $2.64 \pm 0.80$ & $2.22 \pm 0.22$ & $1.96 \pm 0.16^{*}$ & $2.36 \pm 0.13$ & $2.26 \pm 0.09$ \\
\hline 12 & $3.20 \pm 0.12$ & $2.32 \pm 0.36^{*}$ & $2.13 \pm 0.34^{*}$ & $3.08 \pm 0.07$ & $2.71 \pm 0.18^{*}$ \\
\hline
\end{tabular}

${ }^{*} p<0.05$ compared with uninfected pigs. 
(lactase and/or $\mathrm{Na}^{+}, \mathrm{K}^{+}$-ATPase) were below the $95 \%$ confidence interval of the mean compared with those of uninfected animals. Therefore, all piglets which were negative for rotavirus excretion had either diarrhea or intestinal injury. We have previously found that some infected piglets begin to excrete rotavirus at a later time point ( $9-16 \mathrm{~d}$ p.i.) (12).

The duration of rotavirus excretion was not significantly affected by TGF $\alpha$ treatment. By the 12 th day p.i., only $2 / 27$ piglets continued to shed viral antigen.

\section{Small Bowel Mucosal Findings}

Jejunal morphology (Fig. 1). Comparing histologic measurements in saline-treated infected piglets to those of agematched uninfected controls, $40-50 \%$ blunting of jejunal villus height was seen at 4 and $8 \mathrm{~d}$ p.i. $(p<0.01)$, with restoration of normal villus height by $12 \mathrm{~d}$ p.i. In contrast, only one group of TGF $\alpha$-treated infected piglets (the group treated with 60 $\mu \mathrm{g} / \mathrm{dL}$ ) had shorter villi than those of uninfected piglets at the 4-d time point. By $8 \mathrm{~d}$ p.i., jejunal villi were reduced $(p<$ 0.01 ) in height in saline-treated pigs and in pigs receiving the lowest dose of TGF $\alpha$; but piglets receiving doses $\geq 60 \mu \mathrm{g} / \mathrm{L}$
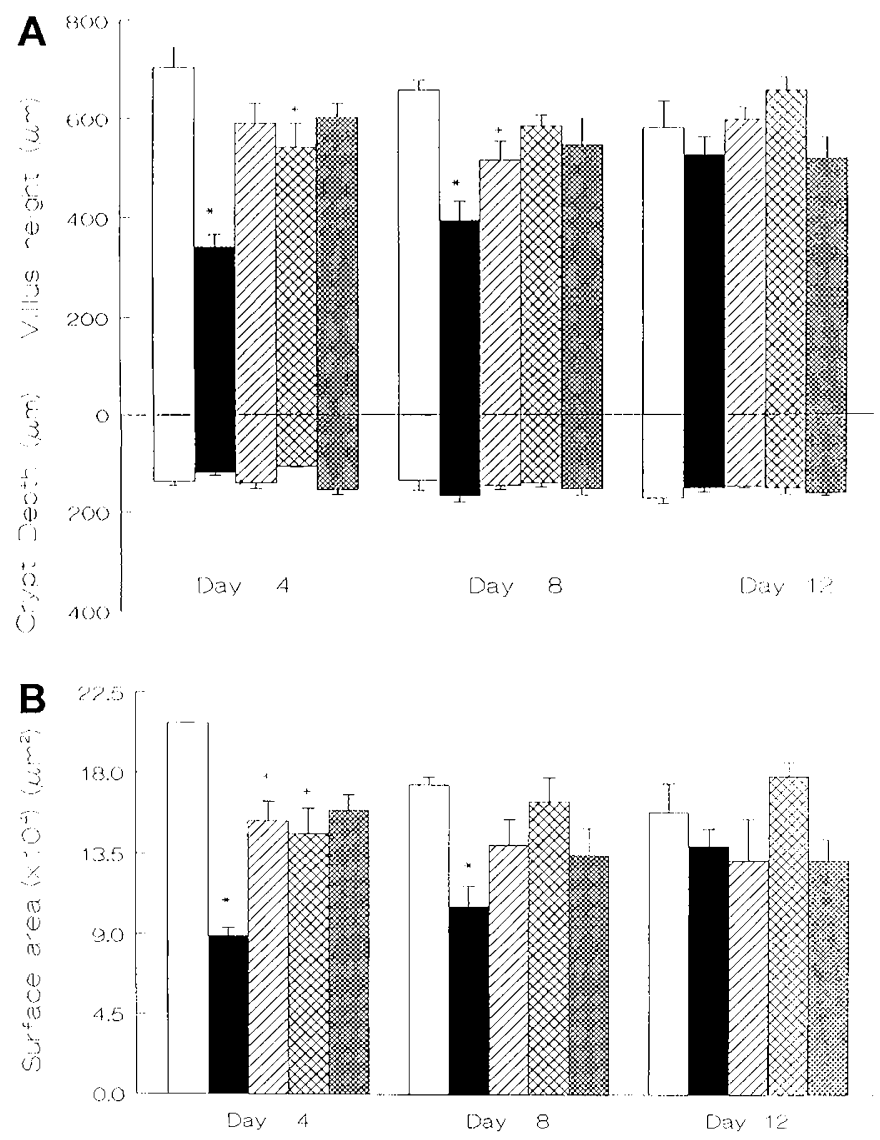

Figure 1. A, Villus/crypt dimensions of piglet mid-jejunum. $n=5-7$ tissues from infected piglets and $8-14$ from uninfected animals at each time point. ${ }^{*} p$ $<0.01$ compared with uninfected. $+p<0.05$ compared with uninfected Mean \pm SEM. $B$, Calculated villous surface area. Uninfected (open bars); rotavirus-infected/saline-treated (solid bars); infected, TGF $\alpha$-treated $(15 \mu \mathrm{g} / \mathrm{L})$ (hatched bars); infected, TGF $\alpha$-treated ( $60 \mu \mathrm{g} / \mathrm{L}$ ) (cross-hatched bars); and infected, TGF $\alpha$-treated $(240 \mu \mathrm{g} / \mathrm{L})$ (gray bars) are as shown.
TGF $\alpha$ had normal villous height. There was no reduction in villus height, compared with villus height of normal uninfected piglets, at any time point in the group that received $240 \mu \mathrm{g} / \mathrm{L}$ TGF $\alpha$. Crypt depth was similar in all animals, regardless of treatment group.

In the infected saline-treated piglets, mucosal villous surface area (absorptive surface) was reduced by $\sim 50 \%$ at 4 and $8 \mathrm{~d}$ p.i. $(p<0.01$ compared with uninfected) (Fig. $1 B)$. Absorptive surface was significantly greater in TGF $\alpha$-treated infected animals at $4 \mathrm{~d}$ p.i. than in their saline-treated infected littermates $(p \leq 0.011)$. By 8 d p.i., none of the TGF $\alpha$-treated groups had a measured villous surface area that differed significantly from control values.

We also counted nucleated cells on the villi of jejunal segments from each treatment group at $\mathrm{d} 4$ and 8 p.i. Counts at d 4 p.i. ranged from $199 \pm 5$ cells in the saline-treated infected group to $239 \pm 10$ cells in the TGF $\alpha(60 \mu \mathrm{g} / \mathrm{L}$ dose $)$-treated group. However, there were no statistically significant differences overall, by the Kruskal-Wallis test $(p=0.09)$. Counts at 8 d p.i. ranged from $199 \pm 5$ (saline-treated) to $239 \pm 10$ (TGF $\alpha 60 \mu \mathrm{g} / \mathrm{L}$ group) ( $p=\mathrm{NS}$ ).

Crypt cell production (Fig. 2). The number of mitoses per microdissected crypt was determined in three groups of piglets: infected animals receiving $60 \mu \mathrm{g} / \mathrm{L}$ TGF $\alpha$ or saline treatment and normal uninfected controls. The number of mitoses per

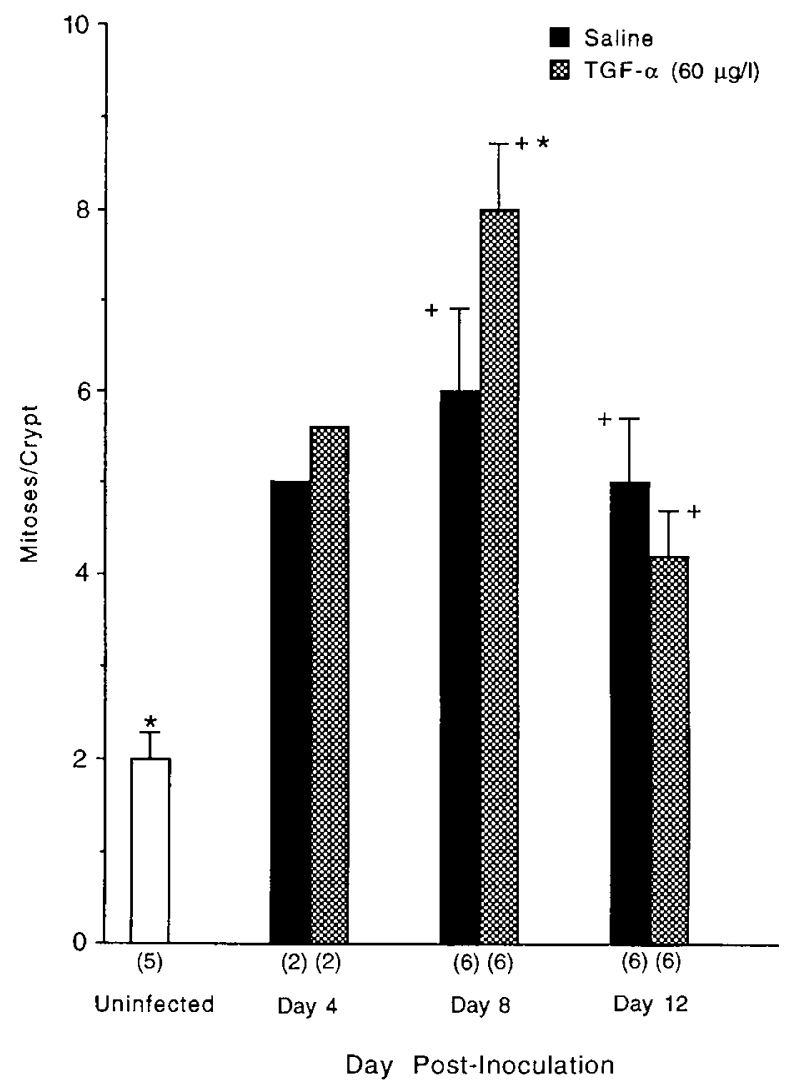

Figure 2. Comparison of the number of mitoses per microdissected crypt in three treatment groups: uninfected (open bars); rotavirus-infected, salinetreated (solid bars); and rotavirus-infected, TGF $\alpha$-treated $(60 \mu \mathrm{g} / \mathrm{L}$, gray bars). Number of observations is in parentheses. $+p<0.05$ compared with uninfected. *Comparing saline-treated and TGF $\alpha(60 \mu \mathrm{g} / \mathrm{L})$-treated groups, $p$ $=0.058$. 
crypt was doubled in both infected groups compared with the controls $(p<0.015)$. This value did not differ between the TGF $\alpha$ - and saline-treated animals at either 4 or 12 d p.i. At 8 d p.i., the number of mitoses in the TGF $\alpha$-treated group was $25 \%$ greater than in the saline-treated group ( $p=0.058$ ), suggesting increased proliferation in response to enteral growth factor.

Mucosal mass (Fig. 3). At d 4 and 8 p.i., there were no differences in mucosal wet weight, comparing the five groups of piglets. Mucosae of the TGF $\alpha$-treated piglets, after $12 \mathrm{~d}$ of treatment, weighed $\sim 50 \%$ more than those of saline-treated infected piglets or normal piglets (Fig. $3 A, p<0.01$ ). This hypertrophy could be observed by visual inspection of the intestine after $12 \mathrm{~d}$ of TGF $\alpha$ treatment (E.O.K. and C.R.F.). Protein content $(\mathrm{mg} / \mathrm{cm})$ of the mucosa of infected pigs generally paralleled the mucosal wet weight, with a $35 \%$ increase in pigs given dietary TGF $\alpha$ at 15 or $60 \mu \mathrm{g} / \mathrm{L}$ for $12 \mathrm{~d}(p<$ $0.05)$.

Mucosal DNA content from saline-treated infected piglets was lower than DNA content in normal tissues at 4 and $8 \mathrm{~d}$ p.i. $(p<0.05)$ (Fig. 3). DNA content of TGF $\alpha$-treated piglet jejunum was not significantly different from that of uninfected piglet intestine, although values were similar to those of salinetreated infected piglets. There was a trend toward increased DNA content in TGF $\alpha$-treated pig jejunum at $12 \mathrm{~d}$ p.i., but the difference was not statistically significant.

The protein/DNA ratio in TGF $\alpha$-treated jejunum was similar to that of saline-treated infected jejunum at each time point (for example, at $12 \mathrm{~d}$ p.i., the ratio was $32.5 \pm 4.7 \mathrm{mg}$ of protein $/ \mathrm{mg}$ of DNA in saline-treated compared with $37.0 \pm 5.0$ in pigs consuming TGF $\alpha=60 \mu \mathrm{g} / \mathrm{L}$ diet).

Mucosal enzymes (Table 2). Mucosal lactase activity was reduced in rotavirus-infected tissues (with a nadir of enzyme activity at $8 \mathrm{~d}$ p.i.). There was a trend for a decrease in lactase activity with increasing postnatal age, as expected with normal development in early weaned animals. By $12 \mathrm{~d}$ p.i., the enzyme activity had was comparable to activity in normal intestine in all groups of infected piglets except for a modest decrease in the group receiving $15 \mu \mathrm{g} / \mathrm{L} \mathrm{TGF} \alpha$. Rotavirus enteritis also caused a reduction of mucosal sucrase-specific activity to $\sim 33 \%$ of normal in saline-treated infected piglets $(p<0.01)$. Sucrase-specific activity was also reduced in TGF $\alpha$-treated piglet jejunum. By $8 \mathrm{~d}$ p.i., sucrase activity had returned to normal only in the group receiving TGF $\alpha$ at $60 \mu \mathrm{g} / \mathrm{mL}$. By 12 $\mathrm{d}$ p.i., sucrase activity was normal in all groups of infected piglets.

$\mathrm{Na}^{+}, \mathrm{K}^{+}$-ATPase activity in the mucosa was reduced by about $50 \%$ in infected piglets at 4 and $8 \mathrm{~d}$ p.i. and then returned to normal; and there was no significant effect of TGF $\alpha$ treatment on its activity. Alkaline phosphatase activity in the jejunal mucosa was reduced in rotavirus-infected piglets, but this enzyme remained abnormal at all three time points in all treatment groups $(p<0.05)$ (not shown). Specific activity of ornithine decarboxylase, the rate-limiting enzyme in polyamine biosynthesis (19), in infected animals was elevated at $\mathrm{d}$ $4-8$ p.i. (1.5-2 times compared with uninfected piglets; $p<$ 0.05 ), but there was no statistically significant difference between mucosal ornithine decarboxylase activity of piglets treated with TGF $\alpha$ and that of their saline-treated littermates (not shown).

Jejunal bioelectric properties and glucose-stimulated $\mathrm{Na}^{+}$ transport. Resistance (defined as 1 /conductance) is a measure of mucosal integrity which is governed by the tight junctions. We noted that at d 12 p.i. most epithelial samples from TGF $\alpha$-treated animals had a high resistance. Furthermore, many more animals with tall jejunal villi $(>600 \mu \mathrm{m})$ had received TGF $\alpha$, rather than saline ( $p=0.0094$ by Fisher's exact test). Electrical resistance decreases with increasing villus height, but generally increases after viral damage (20). The relationship between epithelial resistance and villus height was explored. In saline-treated infected piglet jejunum bathed in Ringer buffer in Ussing chambers $(n=14)$, no significant relationship between villus height and resistance was found (not shown). However, in the (infected) TGF $\alpha$-treated jejunum, a positive linear correlation between villus height and resistance was observed ( $r=0.4, p<0.001$, Fig. 4). The $\mathrm{Na}^{+}$-absorptive response $\left(\Delta \mathrm{I}_{\mathrm{sc}}\right)$ to mucosal D-glucose was essentially the same, comparing the four groups of infected piglets (Table 2).

\section{DISCUSSION}

Previous studies of EGF. EGF and TGF $\alpha$ are trophic peptides in saliva, human milk, and intestinal epithelium (21). In vivo studies, in which EGF was given to animals orally or systemically, have generally shown stimulatory effects of exogenous EGF on the intestine $(7,22-31)$. Parenteral EGF has consistently been shown to enhance intestinal proliferation and in some cases to alter the expression of brush border enzymes. Enteral EGF has been shown to enhance mucosal proliferation and/or intestinal disaccharidase activity in normal intestine. In recent studies of rotavirus-infected piglet intestine and methotrexate-injured rat intestine, enteral EGF added before injury was associated with no clinical improvement, small changes in villus-to-crypt ratio, and a more rapid recovery of mucosal disaccharidases $(30,32)$.

Effect of TGF $\alpha$ on mucosal mass and structure. In the present study, dietary TGF $\alpha$ was given at concentrations similar to but greater than those in human milk (8). Higher than normal concentrations were chosen because human jejunal juice contains proteolytic activity against EGF and TGF $\alpha$ (33). We found that all doses of TGF $\alpha(15-240 \mu \mathrm{g} / \mathrm{L})$ stimulated mucosal villus recovery from rotaviral damage without evidence of functional recovery. Gradual recovery from the rotavirus-induced villus injury required a period of $12 \mathrm{~d}$, but jejunum from TGF $\alpha$-treated animals returned to normal by $8 \mathrm{~d}$ p.i. The villi of the $60 \mu \mathrm{g} / \mathrm{L}$ TGF $\alpha$-treated jejunum were slightly reduced in height at this time point, but the villous surface area was normal. Because viruses in young hosts can induce a prolonged enteropathy, possibly from repeated cycles of enterocyte infection, we wondered if TGF $\alpha$ treatment might have conferred protection against damage. Such an effect has been reported for EGF in preventing gastric mucosal injury and experimental colitis in rats $(22,34)$. However, in our studies the onset, severity, and duration of rotavirus diarrhea were no different in the saline- and TGF $\alpha$-treated animals. Furthermore, 

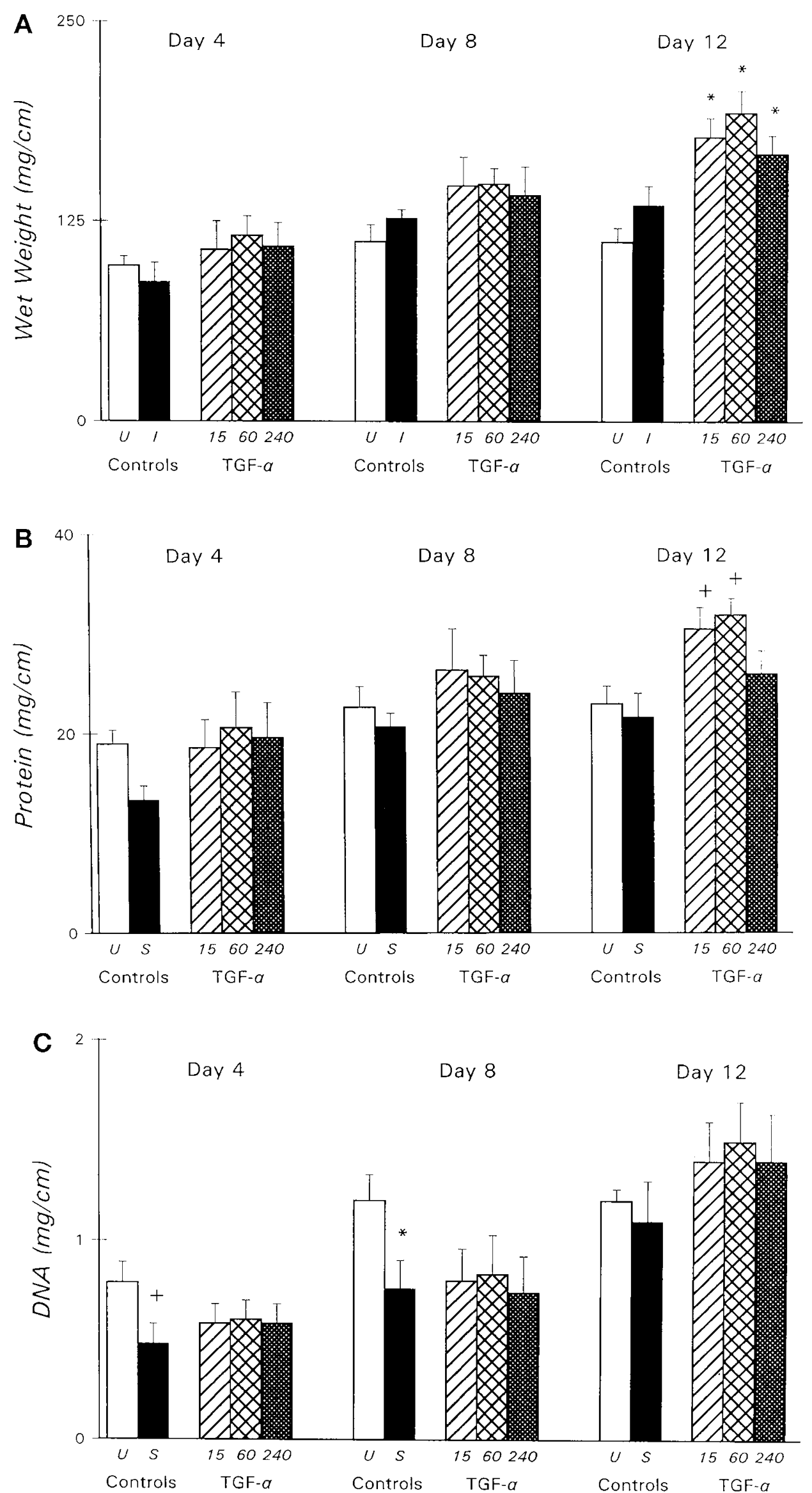

Figure 3. Measurements of mucosal mass. $A$, Mucosal wet weight of piglet jejunum. $B$, Mucosal protein content. $C$, Mucosal DNA content. ${ }^{*} p<0.01$ compared with uninfected jejunum. $+p<0.05$ compared with uninfected tissue. $U=$ uninfected, $I$ or $S=$ infected, saline-treated. 
Table 2. Jejunal enzyme activities and $\mathrm{Na}^{+}$-absorptive response to glucose

\begin{tabular}{|c|c|c|c|c|c|}
\hline & \multirow[b]{2}{*}{ Uninfected } & \multicolumn{4}{|c|}{ Rotavirus-infected } \\
\hline & & Saline & TGF- $\alpha, 15 \mu \mathrm{g} / \mathrm{L}$ & TGF- $\alpha, 60 \mu \mathrm{g} / \mathrm{L}$ & TGF- $\alpha, 240 \mu \mathrm{g} / \mathrm{L}$ \\
\hline \multicolumn{6}{|l|}{4 d p.i. } \\
\hline Lactase & $217 \pm 15(24)$ & $106 \pm 33(6)^{* *}$ & $170 \pm 36(6)$ & $140 \pm 35(6)$ & $127 \pm 36(6)^{*}$ \\
\hline Sucrase & $36.5 \pm 2.5(10)$ & $10.6 \pm 4.3(6)^{* *}$ & $18.5 \pm 3.8(6)^{* *}$ & $17.4 \pm 3.8(6)^{* * *}$ & $19.8 \pm 2.6(6)^{* * *}$ \\
\hline $\mathrm{Na}, \mathrm{K}$-ATPase & $59 \pm 5(15)$ & $28 \pm 7(6)^{* *}$ & $51 \pm 10(6)$ & $45 \pm 12(6)$ & $49 \pm 9(6)$ \\
\hline Glucose-stimulated $\mathrm{I}_{\mathrm{sc}}$ & $2.2 \pm 0.3(6)$ & $3.8 \pm 1.1(6)$ & $2.6 \pm 0.6(6)$ & $2.6 \pm 1.5(6)$ & $1.7 \pm 0.9$ \\
\hline \multicolumn{6}{|l|}{$8 \mathrm{~d}$ p.i. } \\
\hline Lactase & $172 \pm 27(8)$ & $82 \pm 20(6)^{*}$ & $66 \pm 14(5)^{*}$ & $91 \pm 22(6)^{* *}$ & $67 \pm 14(6)^{* *}$ \\
\hline Sucrase & $36.5 \pm 2.5(10)$ & $21.0 \pm 2.4(7)^{* * *}$ & $28.0 \pm 2.4(4)$ & $24.8 \pm 0.7(6)^{*}$ & $17.0 \pm 4.9(6)^{* *}$ \\
\hline $\mathrm{Na}, \mathrm{K}$-ATPase & $68 \pm 13(9)$ & $27 \pm 6(6)^{*}$ & $29 \pm 15(5)$ & $27 \pm 10(6)^{*}$ & $29 \pm 9(6)^{*}$ \\
\hline Glucose-stimulated $\mathrm{I}_{\mathrm{sc}}$ & $3.0 \pm 0.7(7)$ & $2.3 \pm 0.7(6)$ & $2.6 \pm 1.0(5)$ & $3.6 \pm 0.4(7)$ & $3.4 \pm 0.9(6)$ \\
\hline \multicolumn{6}{|l|}{$12 \mathrm{~d}$ p.i. } \\
\hline Lactase & $109 \pm 10(7)$ & $95 \pm 17(6)$ & $76 \pm 12(9)^{*}$ & $82 \pm 9(7)$ & $76 \pm 17(6)$ \\
\hline Sucrase & $36.5 \pm 2.5(10)$ & $26.3 \pm 3.6(6)$ & $24.8 \pm 1.8(8)$ & $28.1 \pm 3.5(7)$ & $22.8 \pm 0.8(5)$ \\
\hline $\mathrm{Na}, \mathrm{K}$-ATPase & $68 \pm 13(5)$ & $32 \pm 10(6)$ & $28 \pm 9(9)$ & $35 \pm 11(7)$ & $31 \pm 12(6)$ \\
\hline Glucose-stimulated $I_{\mathrm{sc}}$ & $3.0 \pm 0.7(7)$ & $3.6 \pm 1.0(6)$ & $3.3 \pm 0.8(8)$ & $2.4 \pm 0.5(7)$ & $3.4 \pm 0.9(6)$ \\
\hline
\end{tabular}

Jejunal specific activities in mucosal homogenates (mean \pm SEM). Some of the data from age-matched uninfected piglets were from control litters reported in previous studies $(11,19)$. Number of observations is in parentheses. Units for lactase and sucrase are $\mu \mathrm{mol} \cdot \mathrm{mg}^{-1} \cdot \mathrm{min}^{-1}$ and for the Na,K-ATPase are $\mathrm{nmol} \cdot \mathrm{mg}^{-1} \cdot \mathrm{min}^{-1}$. Data for glucose-stimulated $\mathrm{I}_{\mathrm{sc}}$ refer to maximal change in transepithelial $\mathrm{I}_{\mathrm{sc}}$ occurring $10-15 \mathrm{~min}$ after $30 \mathrm{mM} \mathrm{D}$.glucose is added to mucosal and serosal baths. ${ }^{*} p<0.05,{ }^{*} p<0.01$ compared with uninfected controls.

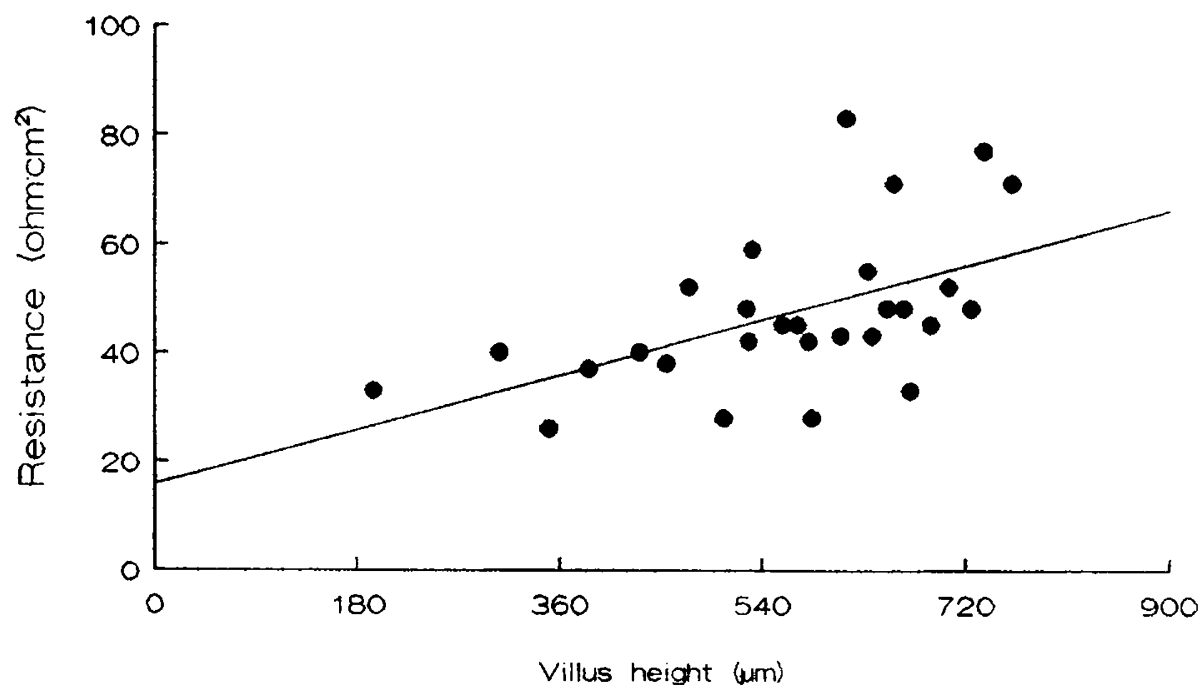

Figure 4. Piglet jejunal electrical resistance as measured in vitro in Ussing chambers of epithelia from piglets treated with enteral TGF $\alpha$. Transepithelial resistance was measured as PD divided by $\mathrm{I}_{\mathrm{sc}}$, plotted against villus height. $r=0.4, p<0.001$.

the duration of viral excretion did not differ between piglets in the different treatment groups.

Despite chronic TGF $\alpha$ exposure, which in theory could down-regulate the physiologic receptor (9), the villi showed an earlier structural recovery (without functional recovery). We believe the increase in crypt cell proliferation to repopulate the injured villi occurred before the 4 -d time point, leading to virtually complete restoration of the mucosal surface. In support of an effect on the crypt, there was a modest increase in crypt cell mitotic rate at $\mathrm{d} 8$ in the TGF $\alpha$-treated bowel (Fig. 2). In addition, the mucosa became hypertrophied after $12 \mathrm{~d}$ of treatment, with greater wet weight and protein content than expected. Mucosal protein content was significantly increased after TGF $\alpha$ treatment, with a similar trend in DNA content (i.e. unchanged protein/DNA ratio). This finding rules against a nonspecific effect, such as tissue edema or altered cell morphology after TGF $\alpha$ treatment. Could the presence of taller villi (in the face of similar DNA content) in the TGF $\alpha$-treated groups compared with the saline-treated infected group be explained by a difference in enterocyte diameter? We were unable to demonstrate such a difference using our morphometry system and measuring enterocyte height and width (data not shown). More likely, the TGF $\alpha$ affected the shaping of the villi. The 8-d TGF $\alpha$-exposed villi (compared with those of salinetreated animals), were actually narrower $(p<0.05)$ and taller $(p<0.05)$, with no significant change in the number of enterocytes per villus (data not shown). This change, at least in part, could result from more rapid resolution of the inflammation in the lamina propria, although no obvious differences were noted among the treatment groups.

The villi of TGF $\alpha$-treated piglet jejunum, whereas normal in height, were populated by cells bearing low digestive enzyme specific activities, suggesting brush border damage or lack of full enterocyte differentiation. The pattern of enzyme activity, 
when expressed per $10-\mathrm{cm}$ bowel length, paralleled the specific activity (not shown). Previous studies of a similar model of infant viral enteritis, transmissible gastroenteritis of piglets, have also demonstrated that recovery of villous height occurs before intestinal enzyme activities return to normal, resulting in a crypt cell-dominated mucosa with reduced disaccharidasespecific activities (35). Because the activity of digestive enzymes and $\mathrm{Na}^{+}, \mathrm{K}^{+}$-ATPase in the TGF $\alpha$-treated piglet intestine were not significantly less than activity in the salinetreated control intestine, we do not believe that chronic TGF $\alpha$ exposure interfered with the differentiation of the enterocytes after repair.

Effect of enteral TGF $\alpha$ on jejunal conductance and $\mathrm{Na}^{+}$ transport in vitro. Based on biophysical considerations (36), epithelia with tall villi were expected to have a greater number of paracellular conductance pathways and therefore a lower resistance. Normal jejunum demonstrated no significant relationship between resistance and villus height (not shown). Inasmuch as a relationship was observed in TGF $\alpha$-treated bowel (Fig. 4), we conclude that TGF $\alpha$ may stimulate villus elongation and resistance of the intestinal barrier. Acutely administered EGF also increased transepithelial resistance in the rabbit ileum, in some of the studies of Opleta-Madsen et al. (37). There is other evidence suggesting that activation of the $\mathrm{EGF} / \mathrm{TGF} \alpha$ receptor could change mucosal barrier function. In burned mice, s.c. recombinant human EGF decreased bacterial translocation into mesenteric lymph nodes and improved mucosal sloughing and villus height in the ileum (38). Interestingly, the EGF receptor has been shown to colocalize with cytoskeletal actin filaments in cultured cells (39), although the physiologic relevance of this observation is unclear.

We recently found that exposure of piglet jejunum to the cyclooxygenase inhibitor indomethacin reduces piglet jejunal $\mathrm{I}_{\mathrm{sc}}$ (a measure of $\mathrm{Cl}^{-}$secretion) and that prostaglandin $\mathrm{E}_{2}$ reduces epithelial conductance (40). We therefore attempted in the present study to minimize any effect of prostaglandins on $\mathrm{I}_{\mathrm{sc}}$ or tissue resistance by bathing tissues in a physiologic saline solution with indomethacin. Changes in current or resistance were therefore expected to be fully attributable to the tissue response to $\mathrm{D}$-glucose in vitro and differences between groups attributable to the presence or absence of TGF $\alpha$.

Acute exposure of rabbit ileum in vitro to EGF $(60 \mu \mathrm{g} / \mathrm{L})$ has been shown to cause an increase in microvillous surface area and in glucose-facilitated $\mathrm{Na}^{+}$absorption, but the investigators subsequently showed that in vitro TGF $\alpha$ treatment of rabbit jejunum did not have these stimulatory effects (41). Chronic exposure of piglet intestine to enteral TGF $\alpha$, in the present study, similarly did not stimulate glucose-coupled $\mathrm{Na}^{+}$ absorption in vitro. Jejunal glucose-sodium cotransport may have recovered fully by $4 \mathrm{~d}$ p.i.

In summary, enteral TGF $\alpha$ at concentrations 2-60 times greater than that found in human colostrum markedly enhanced the rate of regeneration of jejunal villi of piglets with rotavirus enteritis. The epithelium remained undifferentiated, as assessed by enzyme-specific activities and transport function, even after $12 \mathrm{~d}$ of treatment. Because the diarrhea scores improved rapidly even in the untreated piglets, the clinical implications of the beneficial effect of TGF $\alpha$ on mucosal structural recovery are uncertain. We believe the restoration of mucosal structure in response to TGF $\alpha$ could facilitate recovery in more severe types of diarrhea, when repair is delayed, such as diarrhea associated with malnutrition. In addition, further work should determine whether TGF $\alpha$ coadministration with a stimulator of epithelial differentiation (such as TGF $\beta$ ), promotes recovery.

Acknowledgments. The authors thank Robert A. Argenzio for reviewing the manuscript, C. Robert Bagnell for use of the computer-assisted morphometry system, and Jan Huggins, Kevin Fagan, and William Dorsey for expert technical assistance.

\section{REFERENCES}

1. World Health Organization 1990 The rational use of drugs in the management of acute diarrhoea in children. Publication 90/8621

2. Madkour AA, Madina EMH, El-Azzouni OEZ, Amer MA, El-Walili TMK, Abbass T 1993 Smectite in acute diarrhea in children: A double-blind placebo-controlled clinical trial. J. Pediatr Gastroentol Nutr 17:176-181

3. Figueroa-Quintanilla D, Salazar-Lindo E, Sack RB, Leon-Barua R, Sarabia-Arce S, Campos-Sanchez M, Eyzaguirre-Maccan E 1993 A controlled trial of bismuth subsalicylate in infants with acute watery diarrheal disease. N Engl J Med 328:16531658

4. Brown KH, Perez F, Peerson JM, Fadel J, Brunsgaard G, Ostrom KM, MacLean WC 1993 Effect of dietary fiber (soy polysaccharide) on the severity, duration, and nutritional outcome of acute, watery diarrhea in children. Pediatrics 92:241-247

5. Cunningham AS, Jelliffe DB, Jelliffe EFP 1991 Breast-feeding and health in the 1980s: A global epidemiologic review. J Pediatr 118:659-666

6. Connolly JM, Rose DP 1988 Epidermal growth factor-like proteins in breast fluid and human milk. Life Sci 42:1751-1756

7. Ulshen MH, Lyn-Cook LE, Raasch RH 1986 Effects of intraluminal epidermal growth factor on mucosal proliferation in the small intestine of adult rats. Gastroenterology 91:1134-1140

8. Jaeger LA, Lamar DVM, Bottoms GD, Cline TR 1987 Growth-stimulating substances in porcine milk. Am J Vet Res 48:1531-1533

9. Derynck, R 1992 The physiology of transforming growth factor- $\alpha$. Adv Cancer Res 58:27-51

10. Flores J, Nakagomi O, Nakagomi T, Glass R, Gorziglia M, Askaa J, Hoshino Y, Perez-Schael I, Kapikian AZ 1986 The role of rotaviruses in pediatric diarrhea. Pediatr Infect Dis 5:S53-S62

11. Rhoads JM, Keku EO, Quinn J, Woosley J, Lecce JG 1991 L-glutamine stimulates jejunal sodium and chloride absorption in pig rotavirus enteritis. Gastroenterology 100:683-691

12. Lecce JG 1969 Rearing colostrum-free pigs in an automatic feeding device. J Anim Sci 28:27-33

13. Ulshen MH, Lecce JG, Stiles AD, Lyn-Cook LE 1991 Effects of nursing on growth and development of small bowel mucosa in newborn piglets. Pediatr Res 30:337-341

14. Kirstein CG, Clare DA, Lecce JG 1985 Development of resistance of enterocytes to rotavirus in neonatal agammaglobulinemic piglets. J Virol 55:567-73

15. Rhoads JM, Keku EO, Bennett LE, Quinn J, Lecce JG 1990 Development of L-glutamine-stimulated sodium absorption in neonatal piglet jejunum. Am J Physiol 259:G99-G107

16. Cesarone CF, Bolognesi C, Santi L 1979 Improved microfluorometric DNA determination in biological material using 33258 Hoescht. Anal Biochem 100:188-197

17. Lowry OH, Rosebrough NJ, Farr AL, Randall RJ 1951 Protein measurement with the Folin phenol reagent. J Biol Chem 193:265-275

18. Argenzio RA, Liacos JA, Levy ML, Meuten DJ, Lecce JG, Powell DW 1990 Villous atrophy, crypt hyperplasia, cellular infiltration, and impaired glucose-Na absorption in enteric cryptosporidiosis of pigs. Gastroenterology 98:1129-1140

19. McCormack SA, LR Johnson 1991 Role of polyamines in gastrointestinal mucosal growth. Am J Physiol 260:G795-G806

20. Rhoads JM, MacLeod RJ, Hamilton, JR 1986 Alanine enhances jejunal sodium absorption in the presence of glucose: Studies in piglet viral diarrhea. Pediatr Res $20: 879-883$

21. Barnard JA, Beauchamp RD, Russell WE, Dubois RN, Coffey RJ 1995 Epidermal growth factor-related peptides and their relevance to gastrointestinal pathophysiology. Gastroenterology 108:564-580

22. James PS, Smith MW, Tivey DR, Wilson TJG 1987 Epidermal growth factor selectively increases maltase and sucrase activities in neonatal piglet intestine. J Physiol. 393:583-594

23. Goodlad RA, Wilson TJG, Lenton W, Gregory H, McCullagh KG, Wright NA 1987 i.v. but not intragastric urogastrone-EGF is trophic to the intestine of parenterally fed rats. Gut 28:573-582

24. Foltzer-Jourdainne C, Raul F 1990 Effect of epidermal growth factor on the expression of digestive hydrolases in the jejunum and colon of newborn rats. Endocrinology 127:1763-1769

25. Malo C, Menard D 1982 Influence of epidermal growth factor on the development of suckling mouse intestinal mucosa. Gastroenterology 83:28-35 
26. Majumdar APN 1984 Postnatal undernutrition: Effect of cpidermal growth factor on growth and function of the gastrointestinal tract in rats. J Pediatr Gastroentcrol Nutr 3:618-625

27. O'Loughlin EV, Chung M, Hollenberg M, Hayden J, Zahavi I, Gall DG 1985 Effect of epidermal growth factor on ontogeny of the gastrointestinal tract. Am J Physiol 249:G674-G678

28. Jaeger LA, Lamar CH, Cline TR, Cardona CJ 1990 Effect of orally administered epidermal growth factor on the jejunal mucosa of weaned pigs. Am J Vet Res $51: 471-474$

29. Pollack PF, Goda T, Colony PC, Edmond J, Thornburg W, Kore M, Koldovsky O 1987 Effects of enterally fed epidermal growth factor on the small and large intestine of the suckling rat. Regul Pept 17:121-132.

30. Berseth CL 1987 Enhancement of intestinal growth in neonatal rats by epidermal growth factor in milk. Am J Physiol 253:G662-G665

31. Petschow BW, Carter DL, Hutton GD 1993 Influence of orally administered epidermal growth factor on normal and damaged intestinal mucosa in rats. J Pediat Gastroenterol Nutr 17:49-58

32. Zijlstra RT, Odle J, Hall WF, Petschow BW, Gelberg HB, Litov RE 1994 Effcet of orally administered epidermal growth factor on intestinal recovery of neonatal pigs infected with rotavirus. J Pediatr Gastroenterol Nutr 19:382-390

33. Playford RJ, Woodman AC, Clark P, Watanapa P, Vesey D, Deprez PH, Williamson RCN, Calam J 1993 Effect of luminal growth factor preservation on intestinal growth. Lancet 341:843-848
34. Procaccino F, Reinshagen M, Hoffman P, Seeh JM, Lakshmanan J, McRoberts JA, Patel A, French S, Eysselein VE 1994 Protective effect of epidermal growth factor in an experimental model of colitis in rats. Gastroenterology 107:12-17

35. Shepherd RW, Butler DG, Cutz E, Gall DG, Hamilton JR 1979 The mucosal lesion in viral enteritis. Extent and dynamics of the epithelial response to virus invasion in transmissible gastroenteritis in piglets. Gastroenterology 76:770-777

36. Marcial MA, Carlson SL, Madara JL 1984 Partitioning of paracellular conductance along the ileal crypt-villus axis: A hypothesis based on structural analysis with detailed consideration of tight junction structure-function rclationships. J Membr Biol 80:59-70

37. Opleta-Maden K, Hardin J, Gall DG 1991 Epidermal growth factor up-regulates intestinal electrolyte and nutrient transport. Am J Physiol 260:G807-G814

38. Zapata-Sirvent RL, Hansbrough JF, Wolf P, Grayson LS, Nicolson M 1993 Epidermal growth factor limits structural alterations in gastrointestinal tissues and decreases bacterial translocation in burned mice. Surgery 113:564-573

39. Van Bergen en Hencgouwen PMP, Den Hartigh JC, Romeyn P, Verkleij AJ, Boonstra J 1992 The epidermal growth factor receptor is associated with actin filaments. Exp Cell Res 199:90-97

40. Woodard PW, Rhoads JM, Keku EO, Lecce JM 1993 Altered jejunal potassium (Rb) transport in piglet rotavirus enteritis. Am J Physiol 265:G388-G393

41. Hardin JA, Gall DG 1992 The effect of TGF $\alpha$ on intestinal solute transport. Regul Pept 39:169-176 